\title{
Use of transglutaminases in foods and potential utilization of plants as a transglutaminase source - Review
}

\author{
Fernando B. Luciano ${ }^{1}$ * \\ Susan D. Arntfield ${ }^{2}$ \\ ' PPG em Ciência Animal, Escola de Ciências Agrárias e Medicina Veterinária \\ Pontifícia Universidade Católica, BR 376, km 14, CEP 83010-500, São José dos Pinhais - PR, Brazil \\ ${ }^{2}$ Department of Food Science, University of Manitoba, Winnipeg - MB, Canada \\ * Autor para correspondência \\ fernando.luciano@pucpr.br
}

Submetido em 12/03/2012

Aceito para publicação em 13/07/2012

\section{Resumo}

Uso de transglutaminases em alimentos e a potencial utilização de plantas como uma fonte de transglutaminase - Revisão. Transglutaminases (TGases) são enzimas capazes de catalisar reações de transferência de grupos alquila, o que introduz ligações covalentes entre proteínas, peptídeos e aminas primárias. TGases de origem animal foram as primeiras a serem estudadas e são divididas em nove grupos de isoenzimas. Estas enzimas exercem diversas funções no metabolismo da maior parte dos animais, e são $\mathrm{Ca}^{2+}$-dependentes. TGases microbianas e de plantas também foram identificadas, e existe uma vasta heterogeneidade entre suas sequências de aminoácidos. No entanto, parece que todas as transglutaminases possuem uma tríade de aminoácidos específicos em seu sítio catalítico composto por Cys-His-Asp. Esta sequência pode ser encontrada em todas as estruturas terciárias das enzimas estudadas até hoje. As TGases de origem microbiana são extensamente utilizadas para a modificação de alimentos, principalmente devido ao seu baixo custo e facilidade de extração e purificação quando comparadas com as enzimas de origem animal. TGases também são encontradas em grande parte das plantas, e sua utilização para transformação de alimentos já foi proposta. Contudo, a literatura demonstra um único estudo que utiliza TGase vegetal em um alimento, onde a polpa de maçã foi utilizada para melhorar a qualidade da carne de porco. A transferência dos genes de TGase de mamíferos para plantas também tem sido experimentado, sendo que já se conseguiu sua expressão em arroz e folhas de tabaco. Estes resultados podem levar a uma nova técnica de produção de transglutaminases, onde elas poderão ser literalmente plantadas para serem utilizadas em alimentos.

Palavras-chave: Ligação entre proteínas; Plantio molecular; Textura de alimentos; Transglutaminase

\section{Abstract}

Transglutaminases (TGases) are enzymes able to catalyze acyl-transfer reactions introducing covalent cross-links between proteins, peptides and primary amines. Animal TGases were the first studied and are divided in nine different groups of isoenzymes. They have a wide range of functions in the metabolism of most animal cells, and share the characteristic of being $\mathrm{Ca}^{2+}$-dependent. Microbial and plant TGases were also identified, and there is a vast heterogeneity among their amino acid sequences. Interestingly, it seems that all transglutaminases share a specific amino acid triad of Cys-His-Asp in their catalytic site, which can be found in all tertiary structures 
of the enzymes yet studied so far. Microbial TGases are the most widely used for food modification due to lower costs and high yields involved with their extraction and purification when compared to mammal sources. TGases are ubiquitously found in a variety of plants, and their utilization for food transformation has been proposed. However, there is only a single attempt using vegetal TGase in food systems, where apple pomace was used to improve the quality of pork meat. The transference of mammalian TGase genes to plants has also been considered and they were found to be successfully expressed in rice and tobacco leaves. These results lead to a new approach, where TGases could be literally farmed for food utilization.

Key words: Food texture; Molecular farming; Protein cross-link; Transglutaminase

\section{Introduction}

Transglutaminase (TGase) activity was first observed by Clarke et al. (1957) when they found an enzyme with transamidating properties in guinea-pig liver. In the following few decades, transglutaminase activity was described in a variety of living organisms such as yeasts, plants, invertebrates, amphibians, fish and birds (BENINATI; PIACENTINI, 2004).

To date, many transglutaminases have been well characterized in terms of structural and catalytic properties (KIM et al., 1991; 1993; DELLA MEA et al., 2004). This group of enzymes shares the capacity of catalyzing acyl-transfer reactions introducing covalent cross-links between proteins (NONAKA et al., 1989), peptides and primary amines (FOLK et al., 1980). Basically, the reaction occurs when a glutamyl residue is the acyl donor and the $\varepsilon$-amino group of a lysine residue works as an acyl acceptor, then $\varepsilon-(\gamma$-Glu)-Lys bonds can be formed both intra- and inter-molecularly (ZHU et al., 1995). The reaction can also happen in the presence of primary amines, what can cause the incorporation of polyamines in proteins (FOLK et al., 1980). When primary amines are not available in the reaction environment, glutamine can react with water molecules, which acts as the acyl receptor, causing deamidation of the glutamine, and therefore formation of glutamic acid residues (ANDO et al., 1989). All these reactions seem to play an important role during the cell metabolism of all kinds of organisms yet studied (Figure 1).

Mammal TGases have been the most intensively researched (FOLK et al., 1980; KIM et al., 1991; 1993; KAMURA et al., 1992), but TGases have also been found in plant tissues (ICEKSON; APELBAUM, 1987; FALCONE et al., 1993; KANG; CHO, 1996;
LILLEY et al., 1998; VILLALOBOS et al., 2004) and microorganisms (ANDO et al., 1989; KASHIWAGI et al., 2002). Studies implying the purification, characterization and application of guinea-pig liver TGase have been reported as early as the 1960s (FOLK; COLE, 1965; 1966; FOLK et al., 1980). Animal transglutaminases were found to be $\mathrm{Ca}^{2+}$-dependent and are stereochemically characterized by a catalytic triad of cysteine, histidine, and aspartate (or asparagine), with the reaction occurring via an intermediate linked to the cysteine (BENINATI; PIACENTINI, 2004). This cysteine residue plays a central role during the acyl transfer reaction, and its substitution by alanine was found to cause loss of TGase activity (KANAJI et al., 1993). Plant transglutaminases were studied in such depth by only few researchers (DELLA MEA et al., 2004; VILLALOBOS et al., 2004), and even with low amino acid homology, apparently they carry similar characteristics to animal TGases.

FIGURE 1: Transglutaminase reactions. a) protein cross-link; b) incorporation of amines; and c) deamidation.

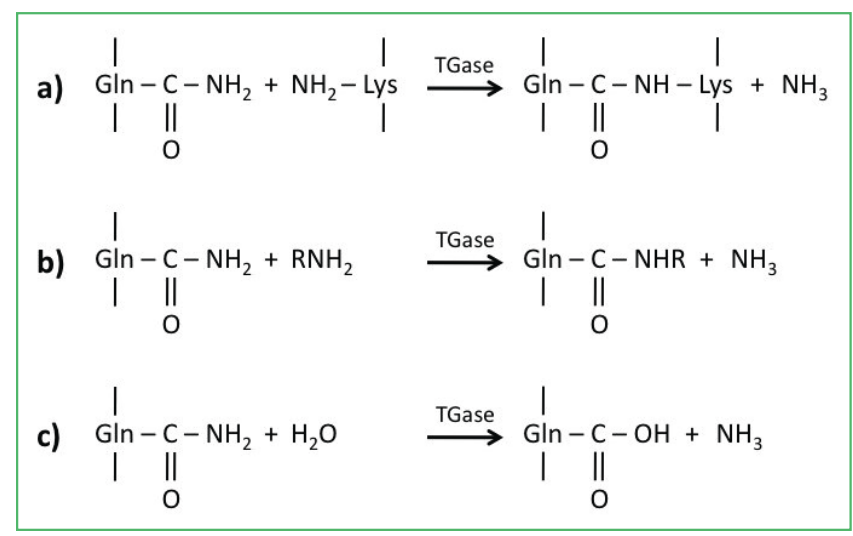

Currently, transglutaminase-catalyzed reactions have been used to alter the functional properties of food proteins, including soya and whey proteins, casein, 
gluten, myosin and actomyosin (IKURA et al., 1980; 1981; MOTOKI et al., 1984; LIU; DAMODARAN, 1999; VÁCHA et al., 2006). The action of TGase over these proteins may result in the improvement or differentiation of a food product. Researchers have used TGases for a wide variety of applications, and studies have shown the utilization of TGases in food products to improve protein encapsulation capacity, produce textured products, change elasticity and water-holding capacity of proteins, form heat and water resistant films, improve the nutritious value of food products by adding essential amino acids, modify protein solubility and avoid thermal treatment for gelation (JONG; KOPPELMAN, 2002).

Until the early 90's, the only commercial source of transglutaminase was derived from guinea-pig liver, and had a complicated method of separation and purification resulting in high prices (ZHU et al., 1995). It was in the late 80 's that TGase activity was firstly described from Streptoverticillium species (ALDO et al., 1989), what caused a revolution in the commercialization of the enzyme. Growth of this yeast in bioreactors eased the isolation of TGase in much higher amounts and consequently dropped the prices. Nowadays, the main source of the enzyme is microbial fermentation, which is greatly dominated worldwide by two companies (TORNÉ et al., 2007).

Plant transglutaminases and their capacity for food protein alteration seem to be almost forgotten. Only a few research groups have dedicated their efforts to understand the structure, characteristics and functionalities of these enzymes, and even fewer have pointed out their potential utilization in food products. In this report, the most extensively studied TGases and their features are reviewed, especially those derived from plants.

\section{Mammalian transglutaminases}

The first transglutaminase identified was derived from guinea-pig liver (FOLK; COLE, 1965), but this enzyme has been identified in many other mammal species. In mammals, the superfamily of transglutaminases was sub-classified in nine different types of isoenzymes, and only of them six have been isolated and characterized at the protein level. The amino acid sequence within the different classes of TGases presents some homology but it is not highly conserved. Similarly, their active site region includes a catalytic triad of Cys-His-Asp or Cys-His-Asn, which is dependent on of $\mathrm{Ca}^{2+}$ binding for activation (BENINATI; PIACENTINI, 2004).

Among all the mammalian TGases, factor XIII of the coagulation cascade is one of the most studied and its physiological role is well established (SERAFINIFRACASSINI et al., 1995). Structurally, this protein is formed by four sub-units with a molecular size of $320 \mathrm{kDa}$ and is considered as a TGase type II. In the tetramer, two pairs of identical units called "a" (MW $=75 \mathrm{kDa})$ and "b" $(\mathrm{MW}=80 \mathrm{kDa})$ result in a soluble protein which travels in the bloodstream (ICHINOSE; DAVIE, 1988). The sub-units "a" contain the catalytic sites and need calcium for activation, whereas the "b" sub-units seem to have a role on the transportation, protection and stabilization of the catalyitic domains (SCHWARTZ et al., 1973). Studies aiming to understand better the structural characteristics of the factor XIII found that the catalytic sub-units are folded in four different regions and the catalytic triad is localized in the core region (YEE et al., 1994). The same authors also proposed that the factor XIII has structural similarities to catabolic enzymes such as cysteine proteases, however executing the exact opposite function. Factor XIII can also be synthesized as a simple and functional $\mathrm{a}_{2}$ dimer in platelets, macrophages and placenta (KAMURA et al., 1992).

The best studied example of type I TGase is a keratinocyte-derived (TGase K) enzyme found to be expressed in cultured epidermal keratinocytes, epithelial tissues and rat chondrosarcoma. Different from factor XIII, the TGase $\mathrm{K}$ is a membrane-bound enzyme with a molecular weight of approximately $90 \mathrm{kDa}$. Structural analysis revealed that the enzyme is mainly hydrophobic in nature and has characteristics of a globular protein (KIM et al., 1991). Epidermal TGase (TGase E) is another TGase found in the human epidermis and is classified as a TGase type III. It was identified as a proenzyme of $77 \mathrm{kDa}$, which needs to be enzymatically cleaved into a $50 \mathrm{kDa}$ fragment to exert its function of 
cell envelope formation in the epidermis and hair follicle (KIM et al., 1993).

Apart from those three TGase types, others were found in almost all human tissues, located in all cell regions (cytoplasm, nucleus, membrane, mitochondria) and even extra-cellularly (SERAFINI-FRACASSINI; DEL DUCA, 2008). Evidences of their functions are as wide as their amino acid sequences, and their possible responsibilities involve membrane stiffening of erythrocytes, facilitation of fertilization by masking the immunogenic potential of the spermatozoa, receptor mediated endocytosis, tumor metastasis, apoptosis, regulation of cell differentiation and growth (SERAFINI-FRACASSINI et al., 1995). Researchers have also correlated the action of tissue transglutaminases (tTGase) over gliadin in the pathogenesis of celiac disease (SJÖSTRÖM et al., 1998; CAPUTO et al., 2004). The hypothesis includes the possible deamidation of certain glutamine residues of gliadin by tTGase, which can be recognized as epitopes by T-cells, leading to the inflammatory disease (SKOVBJERG et al., 2002).

\section{Microbial transglutaminase}

The first publications proposing the production and commercial utilization of transglutaminase derived from microorganisms were reported during the late 1980s. Ando et al. (1989) screened thousands of microbial strains isolated from soil samples originated from diverse locations. Among the microorganisms studied, Streptoverticillium $S$-8112 showed the capacity of producing an extracellular transglutaminase. It was the first transglutaminase isolated from a non-animal source. Different from mammalian TGases, this enzyme is not $\mathrm{Ca}^{2+}$-dependent. A few years later, Kanaji et al. (1993) determined the amino acid sequence of the Streptoverticillium S-8112 TGase and compared it to the well-studied mammalian coagulation factor XIII and guinea pig liver TGase. The authors identified low levels of homology between the microbial TGase and the $\mathrm{Ca}^{2+}$-dependent mammalian TGases sequences, with the exception of the region around the single $\mathrm{Cys}^{64}$ residue, which plays a paramount role for the catalytic activity. The primary amino acid sequence of the microbial TGase was far different from the mammalian enzymes, but the catalytic cysteine showed evidence of being situated in a $\beta$-turn configuration, responsible for linking $\alpha$-helix and $\beta$-sheet structures. This secondary formation correlates well with those found in the subunit "a" of blood coagulation factor XIII and guinea pig liver TGase. As a result, the authors suggested that the conformational structure of the active site, where the Cys resides, is probably similar between the microbial and the mammalian TGases.

Kashiwagi et al. (2002) determined the crystal structure of a transglutaminase from Streptoverticillium mobaraense and showed that its overall structure is widely different from the mammalian coagulation factor XIII. However, the catalytic triad composed by the amino acids $\mathrm{Cys}^{64}, \mathrm{Asp}^{255}$ and $\mathrm{Hys}^{274}$ were found to three-dimensionally superimpose well on the catalytic triad "Cys-His-Asp" of the factor XIII, confirming the hypotheis of Kanaji et al. (1993). Interestingly, the microbial transglutaminase showed characteristics considered valuable for commercial purposes, such as higher catalytic rate, smaller size, broader substrate specificity and lower deamidation activity (KASHIWAGI et al., 2002). Additionally, the enzyme produced by Streptoverticillium sp. is an extracellular enzyme, which is released in the fermentation broth during the microbial growth. Thus, the enzyme can be recovered by the separation of the broth from the solid material (ZHU et al., 1995).

Duran et al. (1998) reported the capacity of transglutaminase expression by Streptoverticillium cinnamoneum and found high amino acid homology with the transglutaminase produced by Streptoverticillium S-8112. Surprisingly, the physiological function of microbial TGases is not fully understood even though many studies were published reporting their structural characteristics (KANAJI et al., 1993; DURAN et al., 1998; KASHIWAGI et al., 2002). Iranzo et al. (2002) suggested that transglutaminase may be involved in the formation of covalent cross-links between proteins during cell wall construction of Saccharomyces cerevisiae. In addition, some studies have shown that TGases are involved in the assembly of spore coat proteins of the genus Bacillus through epsilon-(gammaglutamyl)lysine bonds (KOBAYASHI et al., 1998; ZILHÃO et al., 2005; PLÁCIDO et al., 2008). 


\section{Plant transglutaminases}

Transglutaminase activity in plant tissues has been described for a couple of decades (ICEKSON; APELBAUM, 1987), but only few researchers focused their attention to understand the characteristics and physiological roles of these enzymes. The main excuses for this lack of interest are related to the difficulties for their purification and low amino acid homologies with the well-known animal and microbial transglutaminases (TORNÉ et al., 2007).

The first observations of TGase-like activity in plants were detected in pea seedlings (ICEKSON; APELBAUM, 1987) and sprout apices of Helianthus tuberosus (SERAFINI-FRACASSINI et al., 1988). Icekson and Apelbaum (1987) prepared Pisum sativum extracts from the apical meristematic tissue of etiolated pea seedlings. The extracts showed the capacity to catalyze the cross-linking of radioactively labeled putrescine with proteins in a time and protein concentration-dependent manner. The authors demonstrated that putrecine could be incorporated easily to casein, which is a common transglutaminase substrate. This reaction was found to be enhanced by $\mathrm{Ca}^{2+}$, similar to animal transglutaminases. Additionally, the transglutaminases present in the pea seedling extract were also able to catalyze the binding of ${ }^{3}[\mathrm{H}]$ putrescine with other proteins known as substrates of mammalian TGases, such as fibrinogen, thrombin, pepsin and insulin. Additional evidences suggested that the plant transglutaminases present in the extract were most probably located as free cytoplasmic enzymes rather than bound to a membrane.

Kang and Cho (1996) reported transglutaminase activity in the leaves of soybean (Glycine max) plants. The molecular weight of the enzyme was found to be $80 \mathrm{kDa}$ by gel filtration, which was confirmed when a thick band was found at $80 \mathrm{kDa}$ using sodium dodecyl sulfate polyacrylamide gel electrophoresis (SDS-PAGE). The enzymatic activity presented an optimum $\mathrm{pH}$ of 7.6 at $37^{\circ} \mathrm{C}$, which coincides with other TGases values. It was also demonstrated that the purified enzyme could work even in the absence of $\mathrm{Ca}^{2+}$. This is a characteristic found in microbial TGases (KANAJI et al., 1993), but not in mammalian TGases (BENINATI; PIACENTINI,
2004). In addition, results showed that the enzyme was able to cross-link dimethyl casein with putrescine, spermidine and spermine. Putrescine presented the higher $\mathrm{Km}$, followed by spermine and spermidine. The enzyme was inhibited by guanosine-5'-triphosphate (GTP) in a concentration-dependent manner, as was found with animal tissue transglutaminase.

Studies with corn (Zea mays) detected a unique $58 \mathrm{kDa}$ band codifying a TGase in meristematic calli and chloroplasts, whose expression was found to be light-sensitive (BERNET et al., 1999). More recently, a study compared the transglutaminase activity in different organs of Helianthus (leaves, tubers, sprouts and flower buds) and the results showed that the enzyme could be ubiquitously found in the plant, and some of the organs have multiple forms of the enzyme (DEL DUCA; SERAFINI-FRACASSINI, 2005). Lilley et al. (1998) extracted protein from roots and shoots of dicotyledonous (pea and broad bean) and monocotyledonous (wheat and barley) plants and found that the extracts were able to catalyze the cross-linking of cadaverin (amine donor) and dimethyl casein (amine receptor). Roots had higher TGase activity than leaves. However, the enzymatic activity was higher in pea roots during early stages of growth and significantly reduced with time, whereas it was relatively constant in the leaves during the all period that plants were examined.

As mentioned before, transglutaminase activity has been well-known in plants for many years, but it was only recently that Della Mea et al. (2004) first described and characterized a plant gene that encodes a transglutaminase enzyme. This gene, encoding 721 amino acids, was identified in Arabidopsis and named as AtPng1p. The new protein had a totally different amino acid sequence compared to other previously characterized TGases. However, two cysteine residues were found in the first enzymatic domain, a hystidine residue in the second and an aspartate residue within the third (Figure 2). These residues were suggested to form the catalytic triad in the tertiary structure of the protein, similarly to animal and microbial transglutaminases. Additionally, the TGase activity of the identified protein was confirmed by cross-linking radioactively labeled spermidine, putrescine and spermine to dimethyl 
FIGURE 2: Alignment of the catalytic domain of transglutaminases from different species. A) represents the sequence for AtPng1p Arabidopsis; B) CePhg1p - Caenorhabditis elegans; C) mPng1p - mouse; and D) Factor VIIIa - human. Adapted from Della Mea et al. (2004).

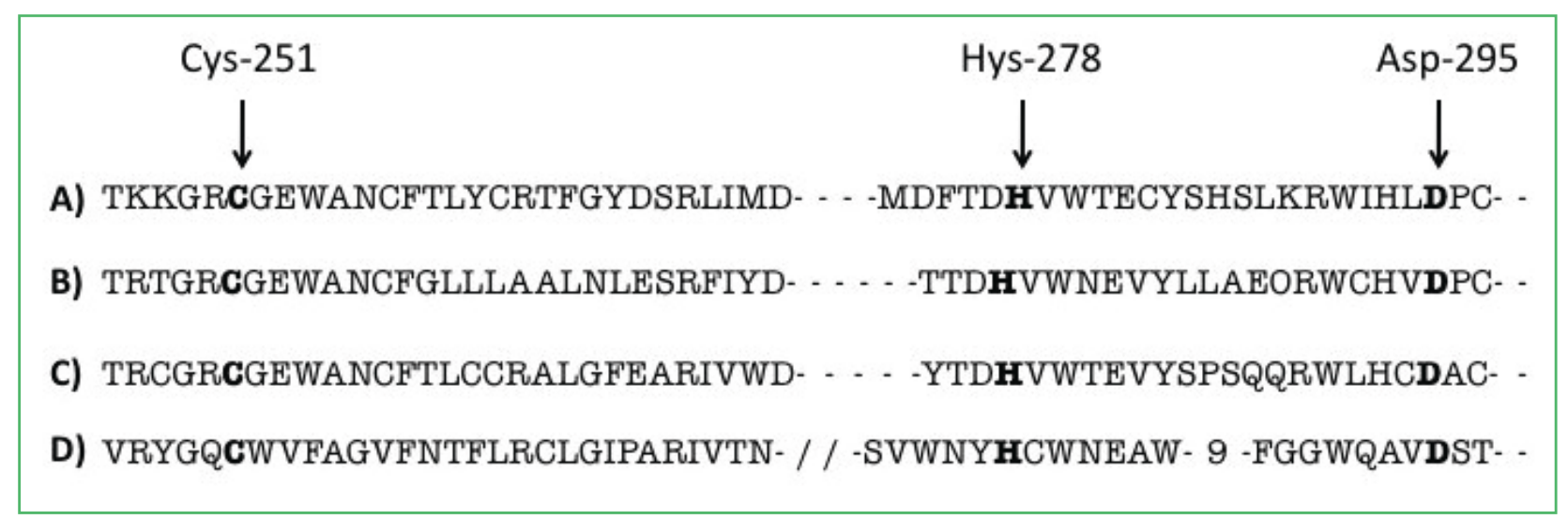

casein. Like mammalian TGases, the AtPng1p protein activity was $\mathrm{Ca}^{2+}$-dependent and could be inhibited by the presence of GTP. Optimum $\mathrm{pH}$ was found at 8.5, and the expression of the gene was found at low levels throughout the plant.

Serafini-Fracassini et al. (2009) corroborated that the AtPng1p protein has the Cys-Hys-Asp catalytic triad and compared the three-dimensional structure of the enzyme with the human TGase type 2 . They found very low homology between the proteins, but confirmed the expectations of Della Mea et al. (2004) about the similarities of the plant enzyme and other TGases in the catalytic site region.

Besides the AtPng1p gene, two DNA clones encoding TGases were also identified in maize samples and named as TGZ15 and TGZ21. These genes were found to be expressed mainly in young leaves and callus. Similar to the Arabidopsis protein, the maize TGases presented $\mathrm{Ca}^{2+}$-dependency, inhibition by GTP, and according to Bernet et al. (1999) their production was stimulated by light, being active mainly in the chloroplast (VILLALOBOS et al., 2004).

The functions of transglutaminases in plant cells are still not well established. The evidence showing that some TGases are light sensitive led to the hypothesis that they might stabilize photosynthetic complexes (BERNET et al., 1999; VILLALOBOS et al., 2004), and perhaps participate in the photosynthesis process. Some reports also suggest that plant TGases may be involved in protein differentiation, leading to a variety of metabolic roles such as cell wall construction, cytoeskeletal modification (DEL DUCA; SERAFINIFRANCASSINI, 2005), fertilization (DEL DUCA et al., 1997), apoptosis and aging (SERAFINI-FRACASSINI et al., 2002).

\section{Food applications of transglutami- nases}

Proteins are an important fraction of food products and play an important role in food texture. The exploitation of TGase to cross-link food proteins and therefore to change their functionalities started in the early 80's (IKURA et al., 1980; 1981; MOTOKI et al., 1984). The first TGases used were from animal origin, and they were able to cross-link important food proteins, such as casein and soy proteins. The modifications caused by the TGase activity also altered protein functionalities including gelation, solubility and emulsifying properties (MOTOKI et al., 1984; NIO et al., 1986). Unfortunately, industrial utilization of TGases at that time was practically impossible due to the high costs of enzyme extraction and purification. Despite this, a patent was published with commercial interests of using mammalian TGases for binding fish and meat parts (JONG; KOPPELMAN, 2002). When Ando et al. (1989) identified the production of an extracellular TGase from a Streptoverticillium strain, the industrial utilization of the enzyme became feasible. Since then, 
several patents have been published regarding the identification, production, isolation and utilization of microbial TGases, but only Ajinomoto Co., Inc. (Tokyo, Japan) and Rohm Enzyme (USA) practically retain the oligopoly of the worldwide TGase commercialization (TORNÉ et al., 2007).

All three main reactions involved with transglutaminases can be used for food transformation: 1) cross-linking between protein-protein; 2) crosslinking between protein-polyamine; or 3) reaction between protein-water resulting in the deamidation of the glutamyl residues of the protein (JONG; KOPPELMAN, 2002).

Residues of glutamines and lysines have to be exposed to the TGase for protein cross-linking reactions in a food system. The reaction will continue as long as those two amino acids are available and spatially reachable to the enzyme. One of the main consequences of food protein cross-linkage is the formation of gels. Moreover, the strengthening of the protein network also results in tougher texture of the final product. Transglutaminases are also used in food products missing or with low levels of lysine to cause deamidation of glutamine residues. The result of this reaction can improve some protein functionalities such as solubility, emulsification, foam formation and gelation characteristics (HAMADA, 1994). Ohtsuka et al. (2001) successfully used TGase in order to deamidate $45 \%$ and $38 \%$ of the glutamine residues of casein and gliadin, respectively.

The functional changes in proteins by TGases have helped researchers in various areas of the food industry. Ozer et al. (2007) have shown that the addition of microbial TGase in a non-fat yogurt can enhance gel strength and reduce syneresis. Moreover, the authors found that the yogurt presented not only enhanced physical properties but also better sensorial characteristics than the non-treated control yogurt, even after 21 days. Gluten-containing products are also affected by TGases. Collar and Bollaín (2004) mixed a microbial TGase in wheat flour dough and found better viscoelastic properties, stability and water-holding capacity in the final baked bread.
Among all food products, TGases have been more extensively used in meat and meat derivates. First, myosin and actin can be cross-linked by TGase (KAHN; COHEN, 1981), contributing to the manufacture of products such as sausages and ham. In addition, large amounts of meat bound to the animal carcasses are lost or sold as low value products. This meat can be restructured by forming gels with the action of TGase, then shaped and flavoured for posterior packaging of a value-added product. This is the basis of crab imitations and kamaboka, which are products derived from surimi gels (JONG; KOPPELMAN, 2002). Another application of microbial TGase in meat products is to readjust the characteristics lost in PSE (pale, soft and exsudative) meats. This type of meat is usually derived from stressed animals and is characterized by its light color, soft consistency and low water-hold capacity, leading to a product of lowered culinary and processing value. Olkiewicz et al. (2003) reported that microbial TGase was able to re-aggregate some of the released proteins, impacting positively on the consistency of the ham produced from PSE meat.

The recommended dose for microbial transglutaminase use in meat products in the USA is $65 \mathrm{ppm}$. Additional applications of this enzyme are in the manufacture of low-density gelatins, low-fat tofu, cheeses, ice creams and a variety of products (TORNÉ et al., 2007).

\section{Potential utilization of plant TGs as food additive}

Presently, all transglutaminases used in industrial scale for food modification are produced by microbial organisms and no other source has shown the ability to compete commercially in this market (TORNÉ et al., 2007). Animal TGases require sophisticated methods of extraction and isolation with low yield rates, resulting in extremely high prices (ZHU et al., 1995). Plant transglutaminases were identified in the late 80 's, but it was only recently that they were proposed as food modifying agents (TORNÉ et al., 2007). The authors identified DNA sequences encoding transglutaminases in maize and patented their possible utilization in food manipulation and transformation. 
Carvajal-Vallejos et al. (2007) published a report where they suggest the transference of a corn-derived TGase gene to bacteria. They successfully transferred the TGZ4p gene to E. coli BL21 and were able to collect high yields of active enzyme with similar catalytic features found in other TGases. The gene encoded a $\mathrm{Ca}^{2+}$-dependent $55 \mathrm{kDa}$ enzyme, which was inhibited by GTP. The authors proposed the industrial utilization of this TGase and are currently testing the production of the enzyme on a 5-litre bioreactor scale.

A single study performed by Lantto et al. (2006) tested the effects of a vegetal transglutaminase in a food product. In this work, apple pomace was found to present both transglutaminase and polyphenol oxidase (PPO) activity, and the effect of these enzymes on pork meat homogenate was surveyed. The results obtained with the apple pomace were compared to commercial microbial TGase and mushroom PPO. The authors reported that only the microbial transglutaminase and the apple pomace were able to enhance the gelation characteristics of pork meat during heat-gelation process in a dose-dependent way, but this effect was not found with the meat treated with mushroom PPO. It seems that the TGase and the apple pomace were able to cause the formation of cross-links between proteins before heating. To confirm the hypothesis that the enzymes can cause protein cross-linking at low temperature, the pork meat was treated with the microbial TGase, mushroom PPO and apple pomace for 1.5 and $22 \mathrm{~h}$ at $4^{\circ} \mathrm{C}$. After $1.5 \mathrm{~h}$, samples treated with TGase and apple pomace already showed significantly harder structures than nontreated control. On the other hand, all groups showed significantly higher hardness after $22 \mathrm{~h}$ of treatment, following the order TGase $>$ apple pomace $>$ mushroom PPO. Even with lower activity than the microbial TGase, it seems that the utilization of apple pomace is suitable for the improvement of pork meat protein functionalities.

Capell et al. (2004) suggested the utilization of molecular farming for producing transglutaminases. They pointed that all TGases currently used are isolated directly from their native source, what usually implies an expensive, dangerous and time-consuming process. Their proposal suggests the production of TGases in plants through genetic modification, where the plant could overexpress a foreign TGase for its industrial utilization in the food and medical areas. Usually, expression of recombinant proteins is mainly used in microbial cells due to the simpler and faster methodology for gene transference. However, the costs for machinery and specialized employees can be significantly high. The use of molecular farming may be more labourous for the gene transference, but usually the yields of recombinant proteins in plants are extremely high, safe and the enzyme can be produced by regular farming practices, demanding less skilled personnel (TWYMAN et al., 2003). Moreover, plants have an advantage upon the other sources of TGases because they can be added directly in food products without the pricey steps of extraction and isolation. Clarapols et al. (2004) were the pioneers in the production of TGase by molecular farming. They built a gene containing rat prostate TGase DNA sequence posterior to a corn promoter. This gene was introduced in mature rice embryos through DNA bombardment. The success of the gene transference was confirmed by DNA gel blot analysis. RT-PCR analysis confirmed the expression of the mRNA in leaf tissues. The authors found no significant difference in TGase activity between the control and wild-type plants. However, the transgenic plants showed a 5-fold increased activity when stimulated by calcium, whereas no significant difference was found in the TGase activity of the wild-type plants. These results show the potential of using rice to produce a functional mammalian transglutaminase.

Recently, Sorrentino et al. (2009) have utilized Nicotiana tabacum cv Petite Havana SR1 for producing genetically modified plants expressing the recombinant human tissue TGase. This enzyme is well characterized both functionally and structurally, which eased the confirmation of the gene transference and expression. The authors constructed three different recombinant genes, targeting protein expression in the cytoplasm, apoplastic space and chloroplasts of the plant cell. Human tissue transglutaminase production was confirmed in all three regions with levels ranging from 18 to $75 \mu \mathrm{g} / \mathrm{g}$ of leaf material. Conclusively, the authors suggest that the utilization of plants as bioreactors for the production of TGases is suitable and quantities provided are comparable to microbial bioreactors. So far, this technique was only used for production of mammal 
TGases, but molecular farming of microbial TGases and overexpression of plant TGases should also be tested.

\section{Conclusions}

The transglutaminase family indeed possesses a structural heterogeneity among its members, but they all appear to conserve a common spatial conformation in the catalytic site. Current industrial utilization of TGases is mainly restricted for food modification, where microbial TGases play a sole act being the only enzymes used for this purpose. Animal TGases are found to have high costs and low yields, while research on plant TGases for food modification is still immature.

Lantto et al. (2006) showed the potential utilization of apple pomace to improve the functionalities of pork meat proteins. Utilization of corn TGase has also been proposed for food transformation (TORNÉ et al., 2007). In addition, a wide variety of crops have been reported as TGases producers (KANG; CHO, 1996; LILLEY et al., 1998; VILLALOBOS et al., 2004; CHANG et al., 2006), and maybe their potential use for food processing has been underestimated. Molecular farming is another technique that has been proposed as an alternative to reduce costs of plant TGases production (CAPELL et al., 2004; CLAPAROLS et al., 2004), and therefore enhance the commercial competitiveness of these enzymes against the well established microbial TGases.

\section{References}

ANDO, H.; ADACHI, M.; UMEDA, K.; MATSUURA, A.; NONAKA, M.; UCHIO, R.; TANAKA, H.; MOTOKI, M. Purification and characteristics of a novel transglutaminase derived from microorganisms. Agriculture and Biological Chemistry, Tokyo, v. 53, p. 2613-2617, 1989.

BENINATI, S.; PIACENTINI, M. The transglutaminase family: an overview: minireview article. Amino Acids, Vienna, v. 26, p. $367-$ 372,2004

BERNET, E.; CLAPAROLS, I.; DONDINI, L.; SANTOS, M.; SERAFINI-FRACASSINI, D.; TORNÉ, J. M. Changes in polyamine content, arginine and ornithine decarboxylases and transglutaminase activities during light/dark phases in maize calluses and their chloroplasts. Plant Physiology and Biochemistry, Paris, v. 37, p. 899-909, 1999.

CAPELL, T.; CLAPAROLS, I.; DEL DUCA, S.; BASSIE, L.; MIRO, B.; RODRIGUEZ-MONTESINOS, J.; CRISTOU, P.;
SERAFINI-FRACASSINI, D. Producing transglutaminases by molecular farming in plants: minireview article. Amino Acids, Vienna, v. 26, p. 419-423, 2004.

CAPUTO, I.; D'AMATO, A.; TRONCONE, R.; AURICCHIO, S.; ESPOSITO, C. Transglutaminase 2 in celiac disease: Minireview article. Amino Acids, Vienna, v. 26, p. 381-386, 2004.

CARVAJAL-VALLEJOS, P. K.; CAMPOS, A.; FUENTESPRIOR, P.; VILLALOBOS, E.; ALMEIDA, A. M.; BARBERA, E.; TORNÉ, J. M.; SANTOS, M. Purification and in vitro refolding of maize chloroplast transglutaminase over-expressed in Escherichia coli. Biotechnology Letters, Dordrecht, v. 29, p. 1255-1262, 2007.

CHANG, Z.; ZHANG, Z.; LI, Y.; ZHU, Y. Comparison of tissue transglutaminase activity during young panicle development in honglian-type cytomplasmic male sterile rice. Rice Science, Hangzhou, v. 13, p. 193-198, 2006.

CLARAPAROLS, M. I.; BASSIE, L.; MIRO, B.; DEL LUCA, S.; RODRIGUEZ-MONTESINOS, J.; CHRISTOU, P.; SERAFINIFRACASSINI, D.; CAPELL, T. Transgenic rice as a vehicle for the production of the industrial enzyme transglutaminase. Transgenic Research, London, v. 13, p. 195-199, 2004.

CLARKE, D. D.; MYCEK, M. J.; NEIDLE, A.; WAELSCH, H. The incorporation of amines into proteins. Archives of Biochemistry and Biophysics, New York, v. 79, p. 338-354, 1957.

COLLAR, C.; BOLLAÍN, C. Impact of microbial transglutaminase on the viscoelastic profile of formulated bread doughs. European Food Research and Technology, Berlin, v. 218, p. 139-146, 2004. DEL DUCA, S.; BREGOLI, A.M.; BERGAMINI, C.; SERAFINIFRACASSINI, D. Transglutaminase-catalyzed modification of cytoskeletal proteins by polyamines during the germination of Malus domestica pollen. Sexual Plant Reproduction, Heidelberg, v. 10, p. 89-95, 1997.

DEL DUCA, S.; SERAFINI-FRACASSINI, D. Transglutaminases of higher, lower plants and fungi. Progress in Experimental Tumor Research, Basel, v. 38, p. 223-247, 2005.

DELLA MEA, M.; CAPARROS-RUIZ, D.; CLAPAROLS, I.; SERAFINI-FRACASSINI, D.; RIGAU, J. AtPng1p. The first plant transglutaminase. Plant Physiology, Lancaster, v. 135, p. 20462054, 2004

DURAN, R.; JUNQUA, M.; SCHMITTER, J. M.; GANCET, C.; GOULAS, P. Purification, characterisation, and gene cloning of transglutaminase from Streptoverticillium cinnamoneum CBS 683.68. Biochimie, Paris, v. 80, p. 313-319, 1998.

FALCONE, P.; SERAFINI-FRACASSINI, D.; DEL DUCA, S. Comparative studies of transglutaminase activity and substrates in different organs of Helianthus tuberosus. Journal of Plant Physiology, Jena, v. 142, p. 263-273, 1993.

FOLK, J. E.; COLE, P. W. Structural requirements of specific substrates from guinea pig liver transglutaminase. Journal of Biological Chemistry, Baltimore, v. 240, p. 2951-2960, 1965.

FOLK, J. E.; COLE, P. W. Mechanism of action of guinea pig liver transglutaminase. Journal of Biological Chemistry, Baltimore, v. 241, p. 5518-5525, 1966.

FOLK, J. E.; PARK, M. H.; CHUNG, S.; SCHRODE, J.; LESTER, E. P.; HERBET, L. Polyamines as physiological substrates for transglutaminases. Journal of Biological Chemistry, Baltimore, v. 255, p. 3695-3700, 1980. 
HAMADA, J. S. Deamidation of food proteins to improve functionality. Critical Reviews in Food Science and Nutrition, Boca Raton, v. 34, p. 283-292, 1994.

ICEKSON, I.; APELBAUM, A. Evidence for transglutaminase activity in plant tissue. Plant Physiology, Lancaster, v. 84, p. 972974, 1987.

ICHINOSE, A.; DAVIE, E.W. Characterization of the gene for the a subunit of human factor XIII (plasma transglutaminase), a blood coagulation factor. Proceedings of the National Academy of Science of the United States of America, Washington, v. 85, p. 5829-5833, 1988.

IRANZO, M.; AGUADO, C.; PALlOTI, C.; CAÑIZARES, J. $\mathrm{V}$; MORMENEO, S. Transglutaminases activity is involved in Saccharomyces cerevisiae wall construction. Microbiology, New York, v. 148, p. 1329-1334, 2002.

IKURA, K.; KOMETANI, T.; SASAKI, R.; CHIBA, H. Crosslinking of soybean $7 \mathrm{~S}$ and $11 \mathrm{~S}$ proteins by transglutaminase. Agricultural and Biological Chemistry, Tokyo, v. 44, p. 29792984, 1980.

IKURA, K.; YOSHIKAWA, M.; SASAKI, R.; CHIBA, H. Incorporation of amino acids into food proteins by transglutaminase. Agricultural and Biological Chemistry, Tokyo, v. 45, p. $2587-$ 2592, 1981.

JONG, G. A. H.; KOPPELMAN, S. J. Transglutaminase catalyzed reactions: impact on food applications. Journal of Food Science, Chicago, v. 67, p. 2798-2806, 2002.

KAHN, D. R.; COHEN, I. Factor XIIIa-catalyzed coupling of structural proteins. Biochemica et Biophysica Acta, Amsterdam, v. 668, p. 490-494, 1981.

KAMURA, T.; OKAMURA, T.; MURAKAWA, M.; TSUDA, H.; TESHIMA, T.; SHIBUYA, T.; HARADA, M.; NIHO, Y. Deficiency of coagulation factor XIII A subunit caused by the dinucleotide deletion at the 5' end of exon III. Journal of Clinical Investigation, New York, v. 90, p. 315-319, 1992.

KANAJI, T.; OZAKI, H.; TAKAO, T.; KAWAJIRI, H.; IDE, H.; MOTOKI, M.; SHIMONISHI, Y. Primary structure of microbial transglutaminase from Streptoverticillium sp. Strain s-8112. Journal of Biological Chemistry, Baltimore, v. 268, p. 1156511572, 1993.

KANG, H.; CHO, Y.D. Purification and properties of transglutaminase from soybean (Glycine max) leaves. Biochemical and Biophysical Research Communications, New York, v. 223, p. 288-292, 1996.

KASHAWAGI, T.; YOKOYAMA, K.; ISHIKAWA, K.; ONO, K.; EJIMA., D.; MATSUI, H.; SUZUKI. Crystal structure of microbial transglutaminase from Streptoverticillium mobaraense. Journal of Biological Chemistry, Baltimore, v. 277, p. 44252-44260, 2002.

KIM, I. G.; GORMAN, J. J.; PARK, S. C.; CHUNG, S.; STEINERT, P. M. The deduced sequence of the novel protransglutaminase $\mathrm{E}$ (TGase3) of human and mouse. Journal of Biological Chemistry, Baltimore, v. 268, p. 12682-12690, 1993.

KIM, H. C.; IDLER, W. W.; KIM, I. G.; HAN, J. H.; CHUNG, S.; STEINERT, P. M. The complete amino acid sequence of the human transglutaminase $\mathrm{K}$ enzyme deduced from the nucleic acid sequences of cDNA clones. Journal of Biological Chemistry, Baltimore, v. 266, p. 536-539, 1991.

KOBAYASHI, K.; SUZUKI, S.; IZAWA, Y.; YOKOZEKI, I. K.;
MIWA, I. K.; YAMANAKA, S. Transglutaminase in sporulating cells of Bacillus subtilis. Journal of General and Applied Microbiology, Tokyo, v. 44, p. 85-91, 1998.

LANTTO, R.; PLATHIN, P.; NIEMISTO, M.; BUCHERT, J.; AUTIO, K. Effects of transglutaminase, tyrosinase and freeze-dried apple pomace powder on gel forming and structure of pork meat. LWT - Food Science and Technology, Zurich, v. 39, p. 11171124, 2006.

LILLEY, G. R.; SKILL, J.; GRIFFIN, M.; BONNER, P. L. R. Detection of $\mathrm{Ca}^{2+}$-dependent transglutaminase activity in root and leaf tissue of monocotyledonous and dicotyledonous plants. Plant Physiology, Lancaster, v. 117, p. 1115-1123, 1998.

LIU, M.; DAMODARAN, S. Effect of transglutaminase-catalyzed polymerization of $\beta$-casein on its emulsifying properties. Journal of Agricultural and Food Chemistry, Washington, v. 47, p. 15141519, 1999.

MOTOKI, M.; NIO, N.; TAKINAMI, K. Functional properties of food proteins polymerized by transglutaminase. Agricultural and Biological Chemistry, Tokyo, v. 48, p. 1257-1261, 1984.

NIO, N.; MOTOKI, M.; TAKINAMI, K. Gelation mechanism of protein solution by transglutaminase. Agriculture and Biological Chemistry, Tokyo, v. 50, p. 851-855, 1986.

NONAKA, M.; TANAKA, H.; OKIYAMA, A.; MOTOKI, M.; ANDO, H.; UMEDA, K.; MATSURA, A. Polymerization of several proteins by $\mathrm{Ca}^{2+}$ - independent transglutaminase derived from microorganism. Agricultural and Biological Chemistry, Tokyo, v. 53, p. 2619-2623, 1989.

OHTSUKA, T.; UMEZAWA, Y.; NIO, N.; KUBOTA, K. Comparison of deamidation activity of transglutaminases. Journal of Food Science, Chicago, v. 66, p. 25-29, 2001.

OLKIEWICZ, M.; KLOSSOWSKA, B.; POSPIECH, E.; GRZES, B. Effect of selected functional additives in the properties of PSE pork meat. Acta Agrophysica, Lublin, v. 2, p. 367-379, 2003.

OZER, B. H.; KIRMACI, H. A.; OZTEKIN, S.; HAYALOGLU, A.; ATAMER, M. Incorporation of microbial transglutaminase into non-fat yogurt production. International Dairy Journal, Barking, v. 17, p. 199-207, 2007.

PLÁCIDO, D.; FERNANDES, C. G.; ISIDRO, A.; CARRONDO, M. A.; HENRIQUES, A. O.; ARCHER, M. Auto-induction and purification of a Bacillus subtilis transglutaminase (Tgl) and its preliminary crystallographic characterization. Protein Expression and Purification, Madison, v. 59, p. 1-8, 2008.

SCHWARTZ, M. L.; PIZZO, S. V.; HILL, R. L.; MCKEE, P. A. Human factor XIII from plasma and platelets: molecular weight, subunits structures, proteolytic activation, and cross-linking of fibrinogen and fibrin. Journal of Biological Chemistry, Baltimore, v. 248, p. 2395-2407, 1973.

SERAFINI-FRACASSINI, D.; DEL DUCA, S. Transglutaminases: widespread cross-linking enzymes in plants. Annals of Botany, London, v. 102, p. 145-152, 2008.

SERAFINI-FRACASSINI, D.; DEL DUCA, S.; BENINATI, S. Plant transglutaminases. Phytochemistry, New York, v. 40, p. $355-$ $365,1995$.

SERAFINI-FRACASSINI, D.; DEL DUCA, S.; D’ORAZI, D. First evidence for polyamine conjugation mediated by an enzyme activity in plants. Plant Physiology, Lancaster, v. 87, p. 757-761, 1988. 
SERAFINI-FRACASSINI, D.; DEL DUCA, S.; MONTI, F.; POLI, F.; SACCHETTI, G.; BREGOLI, A. M.; BIONDI, S.; DELLA MEA, M. Transglutaminase activity during senescence and programmed cell death in the corolla of tobacco (Nicotiana tabacum) flowers. Cell Death and Differentiation, Oxford, v. 9, p. 309-321, 2002.

SERAFINI-FRACASSINI, D.; DELLA MEA, M.; TASCO, G.; CASADIO, R.; DEL LUCA, S. Plant and animal transglutaminases: do similar functions imply similar structures? Amino Acids Vienna, v. 36, p. 643-657, 2009.

SJÖSTRÖM, H.; LUNDIN, K. E.; MOLBERG, O.; KÖRNER, R.; MCADAM, S. N.; ANTHONSEN, D.; QUARSTEN, H.; NORÉN, O.; ROEPSTORFF, P.; THORSBY, E.; SOLLID, L. M. Identification of a gliadin T-Cell epitope in coeliac disease: general importance of gliadin deamidation for intestinal T-Cell recognition. Scandinavian Journal of Immunology, Oslo, v. 48, p. 111-115, 1998.

SKOVBJERG, H.; NORÉN, O.; ANTHOSEN, D.; MOLLER, J.; SJÖSTRÖM, H. Gliadin is a good substrate of several transglutaminases: possible implication in the pathogenesis of coeliac disease. Scandinavian Journal of Gastroenterology, Oslo, v. 37, p. 812-817, 2002.

SORRENTINO, A.; SCHILLBERG, S.; FISCHER, R.; PORTA, R.; MARINIELLO, L. Molecular farming of human tissue transglutaminase in tobacco plants. Amino Acids, Vienna, v. 36, p. 765-772, 2009.

TORNÉ, J. M.; SANTOS, M.; TALAVERA, D.; VILLALOBOS, E.; RIGAU, J. Maize nucleotide sequence coding for a protein with transglutaminase activity and use therof. US Patent 7,262,057, 28 Aug. 2007. 16 p.

TWYMAN, R. M.; STROGER, E.; SCHILLBERG, S.; CHRISTOU, P.; FISCHER, R. Molecular farming in plants: a technology coming of age? Trends in Biotechnology, Amsterdam, v. 21, p. 570-578, 2003.

VACHÁ, F.; NOVIK, I.; SPICKA, J.; PODOLA, M. Determination of the effect of microbiological transglutaminase on technological properties of common carp (Cyprinus carpio L.) meat. Czech Journal of Animal Science, Prague, v. 12, p. 535-542, 2006.

VILLALOBOS, E.; SANTOS, M.; TALAVERA, D.; RODRIGUEZ-FALCÓN, M.; TORNÉ, J. M. Molecular cloning and characterization of a maize transglutaminase complementary DNA. Gene, Amsterdam, v. 336, p. 93-104, 2004.

YEE, V. C.; PEDERSEN, L. C.; LE TRONG, I.; BISHOP, P. D.; STENKAMP, R. E.; TELLER, D. C. Three-dimensional structure of a transglutaminase: human blood coagulation factor XIII. Proceedings of the National Academy of Science of the United States of America, Washington, v. 91, p. 7296-7300, 1994.

ZHU, Y.; RINZEMA, A.; TRAMPER, J.; BOL, J. Microbial transglutaminase - a review of its production and application in food processing. Applied Microbiology and Biotechnology, Berlin, v. 44, p. 277-282, 1995.

ZILHÃO, R.; ISTICATO, R.; MARTINS, L.O.; STEIL, L.; VÖLKER, U.; RICCA, E.; MORAN, C.P.; HENRIQUES, A.O. Assembly and function of a spore coat-associated transglutaminase of Bacillus subtilis. Journal of Bacteriology, Washington, v. 187, p. $7753-7764,2005$. 